\section{7 分析時間および費用について}

現在,当製鍊所ではガス分析および微量分析を除いて， ほとえど全面的にケイ光X線分析法を採用しているが， 試料交換 および標準試料の 測定時間を含めて，重元素 (銅, ニッケル，コバルト，鉄）約 50 成分の分析時間が 約 2 時間であり，軽元素(カルシウム，イオウ，ケイ素， マグネシウム) 約 35 成分の測定時間が約 3.0〜4.0 時 間である. 本装置では重元素の分析から軽元素の分析に 切替える際に $\mathrm{X}$ 線検出器, 分光結晶, $\mathrm{X}$ 線通路などの交 換とその調整に約 1 時間を要する欠点があるが，これら の点について改良された装置を用いることにより，この 不便它解消することができる.

なお，一成分あたりの分析費用は，装置の原価償却費 や人件費を含めて考元て従来の化学分析費の約半分であ る.

おわりに, 本研究学御督励下さった副所長 相原正氏, 技師長 松尾忠氏，また終始御指導を睗わった分析課長 田中正雄氏に感謝します。

\section{文献}

1) T. J. Cullen : Anal. Chem., 32, 516 (1960).

2) I. A. Hans : Chim. Anal., 42, 236 (1960); Chem. Abstr., 54, 18174 (1960).

3) S. C. Sun : Anal. Chem., 31, 1322 (1959).
4) 中島篤之助, 高橋正雄 : 本誌, 8, 248 (-1959).

ts

Application of the fluorescent X-ray analysis to copper and nickel smelting. Senjyo Tomizawa and Miyoshi Kawahara (Sumitomo Metal Mining Co., Ltd., Bessi Mine Office).

A fundamental research on routine analysis by fluorescent X-ray method in the smelting of copper and nickel has been made. The sample used were ores, mattes and slags, while the elements determined were $\mathrm{Cu}, \mathrm{Ni}, \mathrm{Co}, \mathrm{Fe}, \mathrm{Ca}, \mathrm{S}$, $\mathrm{Si}$, and $\mathrm{Mg}$.

Several representative samples from each lot were chosen to give standard samples, and those were analyzed accurately by the standard chemical methods.

Calibration curves were made from the percentages of elements and their fluorescent X-ray intensities. Twenty nine combinations were obtained from the kinds of sample and the elements to be determined, and analytical conditions characteristic to each combination were given.

The analytical error in each case was given by the variation in the difference of values obtained by fluorescent X-ray analysis and those by the standard chemical method. The standard deviations were $1 \sim 3 \%$ for the prime grade elements and $3 \sim 10 \%$ for most of low grade ones. The errors were comparable with, or even less than, those usually met in the rapid chemical analysis.

(Received Feb. 24, 1962)

\title{
含水溶媒を用い遅延電極を使った直接微分 滴定法によるハロゲンイオンの銀滴定
}

\author{
鹿島哲*
}

含水溶媒を使ってハロゲンイオンの銀滴定を行なうとき，有機溶媒（アルコール類）と水との混合割 合の滴定に及ぼす影響を，銀電極学指示電極とし，液間電位の変動觉避けるため，遅延電極を用いた直 接微分電位差滴定法苍使って検討した，直接微分滴定には，スポイト電極に注射筒と三方ガラス管，ま たは窒素ボンベと三方コックを組合わせた装置を考案して迅速正碓な測定な行なった。 その結果，一般 的にいって溶媒中の有機溶媒の含量の多いほど，また，溶媒の親水性が減るにつれて測定感度が向上し たが, その反面, 測定が困難不安定になることがわかった.

80\%イソプロパノールを溶媒として使うことによって，水のみ觉溶媒としたときより塩素イオン扣よ び臭素イオンの測定感度さそれぞれ 7 倍打よび 3 倍程度向上させるととができた.

\section{1 緒言}

非水溶媒を使う中和滴定1)を行なってきたが, 有機溶 媒を使えば八ロゲン化銀の溶解度積を小さくできるにか

* 国立衛生試験所 : 東京都世田谷区玉川用賀町 2 丁目
かわらず，八ロゲンイオン，特に臭素およびヨウ素イオ ンの銀滴定を有機溶媒を使って行なう報告2) 6)が少ない ので検討を行なってみた.

無機のハロゲン化物は水以外の溶媒にほとえど溶けな いので,試料をまず無関係電解質を含む水溶液に溶かし， 
有機溶媒を加えて滴定を行ない，有機溶媒と水との混合 割合および有機溶媒の性質が滴定に及ぼす影響を調べ た．これらの実験を行なうとき，水溶液を用いた塩橋を 有する電池を使ったのでは，有機溶媒を使うため，およ び滴定中に溶媒の組成が変化するため, 塩橋と試料液と の液間電位は大きく, 変化, 変動もしやすいので，有機 溶媒の滴定に 及ぼす影響を 正確に検討できない。そこ で，液間電位の変動の影響を受けない遅延電極を用いる 直接微分滴定法7（電気的微分滴定法に対乙直接機械的 に微分することから，著者が以前に仮に命名した）を使 い，銀線を指示電極として滴定を行なった。

\section{2 装置および試薬}

\section{$2 \cdot 1$ 装}

カール・フィッシャ一の滴定装置を便宜的に利用し, 滴定フラスコとしては三くびフラスコを用い，スポイト 電極（試料液 $2 \mathrm{~m} l$ が入る）と三方ガラス管扣よび注射 筒 $(10 \mathrm{ml})$ よりなる遅延電極と指示電極を Fig. 1 のよ うにそう入し，厚地の黒布でしゃ光しながら直接微分觉 行なう方法で滴定した。 な扣，スポイト電極のガラス表 面打よび滴定フラスコにはベックマン製の “Desicote” またはシリコン油, FK 96 (350) を塗った。

電位の測定にはベックマン pH 計， GS 型を用い，電 気的しゃへいをしてアースをとり, 温度補正ダイャルを $30^{\circ} \mathrm{C}$ に扣き $\mathrm{pH}$ 目盛りを読んだ。 このとき $1 \mathrm{pH}$ は $60 \mathrm{~m} \mathrm{~V}$ 亿相当し, 補助ダイヤルの 1 目盛りは $0.2 \mathrm{mV}$ になる。

\section{$2 \cdot 2$ 試 薬}

エタノ一ル：特級試薬 $1 l$ 亿硝酸銀 $2 \mathrm{~g}$ 打よび粒状水 酸化ナトリウム $10 \mathrm{~g}$ を加えて分別蒸留したときの $78^{\circ} \mathrm{C}$ の留分.

イソプロパノール：特級試薬 $1 l$ に硝酸銀 $2 \mathrm{~g}$ 抽よび 粒状水酸化ナトリウム $10 \mathrm{~g}$ を加えて分留したときの $82^{\circ} \mathrm{C}$ の留分.

エチレングリコール：特級試薬 $1 l$ 亿硝酸銀 $2 \mathrm{~g}$ 打よ び粒状水酸化ナトリウム $10 \mathrm{~g}$ を加えて分留したときの $198^{\circ} \mathrm{C}$ の留分.

純水：イオン交換樹脂で精製したハロゲンイオンを含 まないもの。

硝酸銀：特級試薬を微粉末とし，光をさえぎりながら 硫酸デシケーターで 12 時間以上乾燥.

塩化ナトリウム：標準試薬, 白色結晶性粉末, $110^{\circ} \mathrm{C}$ で 2 時間以上乾焻.

塩化カリウム: 特級試薬, カロメル電極用で臭素イオ

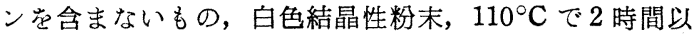
上乾燥.

塩化アンモニウム：特級試薬，白色結晶性粉末，デシ ケーター（シリカゲル）で 12 時間以上乾燥.

臭化カリウム：試薬の臭素酸カリウムを水から再結晶 し，蒸発ザラに入れて赤熱したとき得られた白色粉末.

臭化ナトリウム：薬局方適品, 白色結晶性粉末, $110^{\circ} \mathrm{C}$
で 4 時間以上乾燥.

ヨウ化カリウム：特級試薬，無色透明の結晶, 微粉末 とし $110^{\circ} \mathrm{C}$ で 4 時間以上乾燥.

フタル酸水素カリウム: E. Merck 製, 緩衝液用, 結 晶性粉末, $110^{\circ} \mathrm{C}$ で 2 時間以上乾燥.

銀線：直径 $1.2 \mathrm{~mm}$, 純度 $99.9 \%$ 以上のもの, 徳力 より購入.

$0.02 N$ 硝酸銀標準液（エタノール溶媒）：硝酸銀 $1.7 \mathrm{~g}$ 学 $10 \mathrm{ml}$ の水溶汃し，エタノールを加えて $500 \mathrm{ml}$ と する.

$0.02 N$ 硝酸銀標準液 (イソプロパノール溶媒)：硝酸 銀 $1.7 \mathrm{~g}$ を $10 \mathrm{ml}$ の水に溶かし，イソプロパノールを加 えて $500 \mathrm{ml}$ とする.

$0.02 N$ 硝酸銀標準液 (水溶媒) : 硝酸銀 $1.7 \mathrm{~g}$ 觉約 100 $\mathrm{m} l$ の水に溶汃し, $10 \mathrm{ml}$ の Tween 20 『加えよく振 り混ぜてから水で $500 \mathrm{ml}$ とする.

これらの標準液は塩化ナトリウム約 $50 \mathrm{mg}$ を使って 標定した。

\section{3 実験方法}

1 本の銀線から切り取ってつくった 2 本の銀電極は, その表面をまず目の細かい紙やすりでみがいておき，滴 定のたびごとに硝酸（1:1）に十数秒間つけ，純水でよ く洗ってから使用した。一方の銀電極は指示電極として 直接試料液につけ，他方の電極法試験管の先端を引き延 ばして細い孔を開けたものの中央に保持した「スポイト 電極」をつくり，遅延電極として使った．そのスポイト 電極内の液は，三方ガラス管の開いた口を押さえながら 注射管の内筒を押して排出し, 次にその内筒を引くか, 押さえた指を離すかして液を入れる。このような操作を くり返すことによって迅速にスポイト電極内の液を外側 の試料液と同じ組成にした．また，注射筒と三方ガラス 管の代わりに，窒素ボンベと三方コックとを使って更に 迅速に同じ操作を行なうことができた（Fig. 1).

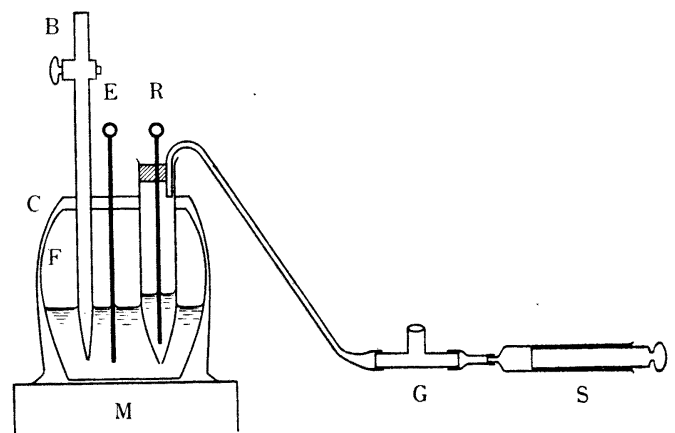

Fig. 1 遅延電極を用いた直接微分滴定装置

\begin{tabular}{|c|c|}
\hline $\mathrm{E}$ : 銀電極（指示電極） & $\mathrm{B}:$ 七ミミクロビ \\
\hline $\mathrm{R}$ : 銀電極（スポイト電極） & F : 滴定フラスコ \\
\hline G : 三方ガラス管 & C : しゃ光用黒布 \\
\hline
\end{tabular}


試料約 0.4 そリモルまたは 0.2 ミリモルと,フタル酸 水素カリウムまたは硝酸 2〜100 ミリモルとを滴定フラ スコにとり, $100 \mathrm{~m} l$ の水を加えて溶かすか, 適当量の水 に溶かしてから有機溶媒を加えて $100 \mathrm{ml}$ とする.

その試料液に硝酸銀標準液 $0.1 \mathrm{~m} l$ を加えてよくかき まぜ, 遅延電極内の液も同じ組成にして両電極間の電位 差, $E_{0}$ を $\mathrm{pH}$ 計で測定した. 次に標準液 $0.1 \mathrm{~m} l$ を加兄 てょくかき混ぜて電位差， $E_{1}$ を測定する。このときス ポイト電極内の液は 1 度目の標準液を加た状態を保つか ら, $\left(E_{1}-E_{0}\right) / 0.1 \mathrm{ml}$ は $\Delta E / \Delta \mathrm{V}$ (電位差の変化/加㫕 た標準液の量）を求めることになる，以上のような操作 をくり返して得られた結果を直接グラフに描き，作図に より $\Delta E / \Delta \mathrm{V}$ の極大で表わされる終点を求めた（直接微 分滴定法)，測定は恒温室 $\left(23 \pm 1^{\circ} \mathrm{C}\right)$ で行ない, 電極は できるでけ接近させ，電気的絶縁をよくして測定した。

\section{4 実 験 結果}

比較のため, ハロゲン化物の水溶液を, 水を溶媒とし た硝酸銀標準液で滴定したところ，Table I にあげた 結果が得られたにこのとき試料液に添加する無関係電解 質の濃度が低いほど測定感度が増大していったが, 測定 は不安定になっていったので, 大多数の測定はフタル酸 水素ナトリウムを加え, その濃度を $0.02 M$ にして行な った.

次に, 試料の水溶液をエタノールを溶媒とした硝酸銀 標準液で滴定したところ, 水を溶媒とした標準液を使っ たときより測定感度がやや向上した (Table II).

また，イソプロパノールを溶媒とした標準液で滴定す ると, 臭素イオンの測定感度が上った (Table III).

試料を含水溶媒に溶かし，イソプロパノールを溶媒と した硝酸銀標準液で滴定したところ，測定感度が前記の 2 種の条件で測定した場合に比べて更に向上した. 有機 溶媒としてェチレングリコールを使ったときは測定感度 の向上はわずかであったが，イソプロパノールを用いた

Table I ハロゲン化物（水溶液）总硝酸銀標準液 （水溶媒）で直接微分滴定

\begin{tabular}{|c|c|c|c|}
\hline 料 & 採取量（g） & 定量值（\%) & 感度 $(\%) \dagger$ \\
\hline 塩化ナトリウム & 0.0301 & 100.0 & 0.035 \\
\hline 塩化カリウム & 0.0318 & 99.7 & 0.035 \\
\hline 臭化ナトリウム & 0.0507 & 98.8 & 0.02 \\
\hline 臭化カリウム & 0.0547 & 99.0 & 0.02 \\
\hline ヨウ化カリウム & 0.0610 & 99.0 & 0.005 \\
\hline
\end{tabular}

加元た無関係電解質 : フタル酸水素カリウム $(0.02 M$ 濃度)

測定値は 3 回の平均值

$\dagger$ 感度 $=\frac{\text { 終点で } 1 \mathrm{mV} \text { の変化を生ずるに必要な標準液の体積 }}{\text { 終点までそ消賸した標準液の体積 }}$
ときは大きかった (Fig. 2 および 3 ).

2 本の銀電極を並べて試料液に入れて滴定したときの 電位の変化は測定精度の範囲 $( \pm 0.1 \mathrm{mV})$ 程度であっ た. 溶媒およびフタル酸水素カリウムのブランク值は標 準液の 1 ～滴であり, 遅延電極を使ったために起る滴 定の遅れによる誤差は無視できる量》であった。なお， 一級試薬の臭化カリウム中には 2 3\% の塭化物が含ま れていた.

Table II ハロゲン化物（水溶液）を硝酸銀標準液 （エタノール溶媒）で直接微分滴定

\begin{tabular}{|c|c|c|c|}
\hline 試 料 & 採取量（g） & 定量值（\%) & 感度 $(\%)$ \\
\hline 塩化ナトリウム & 0.0298 & 100.0 & 0.025 \\
\hline 塩化カリウム & 0.0297 & 99.6 & 0.025 \\
\hline 塩化アンモニウム & 0.0315 & 99.2 & 0.025 \\
\hline 塩化カルシウム & 0.0283 & 99.3 & 0.03 \\
\hline 奥化ナトリウム & 0.0374 & 98.8 & 0.015 \\
\hline 臭化カリウム & 0.0447 & 99.2 & 0.015 \\
\hline$\exists ウ$ 化カリウム & 0.0626 & 99.0 & 0.004 \\
\hline
\end{tabular}

測定値は 3 回の平均值

Table III 種々の溶媒に溶かしたハロゲン化物を 硝酸銀標準液（イソプロパノール溶媒） で直接微分滴定

\begin{tabular}{|c|c|c|c|c|}
\hline 試 料 & $\begin{array}{l}\text { 溶媒の } \\
\text { 組 成 }\end{array}$ & $\begin{array}{c}\text { 採取量 } \\
(\mathrm{g})\end{array}$ & $\begin{array}{c}\text { 定量値 } \\
(\%)\end{array}$ & $\begin{array}{l}\text { 感度 } \\
(\%)\end{array}$ \\
\hline 塩化ナトリウム & $\begin{array}{c}\text { 水 } \\
50 \% \mathrm{G}\end{array}$ & $\begin{array}{l}0.0239 \\
0.0274\end{array}$ & $\begin{array}{r}100.0 \\
99.9\end{array}$ & $\begin{array}{l}0.03 \\
0.025\end{array}$ \\
\hline 塩化カリウム & $\begin{array}{c}\text { 水 } \\
25 \% \mathrm{G} \\
50 \% \mathrm{G} \\
80 \% \mathrm{G} \\
25 \% \mathrm{P} \\
50 \% \mathrm{P} \\
80 \% \mathrm{P}\end{array}$ & $\begin{array}{l}0.0284 \\
0.0310 \\
0.0297 \\
0.0301 \\
0.0285 \\
0.0292 \\
0.0302\end{array}$ & $\begin{array}{l}99.7 \\
99.7 \\
99.6 \\
99.6 \\
99.7 \\
99.6 \\
99.6\end{array}$ & $\begin{array}{l}0.03 \\
0.025 \\
0.025 \\
0.02 \\
0.02 \\
0.015 \\
0.005\end{array}$ \\
\hline 臭化カリウム & $\begin{array}{c}\text { 水 } \\
50 \% \mathrm{G} \\
50 \% \mathrm{P} \\
80 \% \mathrm{P}\end{array}$ & $\begin{array}{l}0.0441 \\
0.0427 \\
0.0446 \\
0.0439\end{array}$ & $\begin{array}{l}98.8 \\
99.0 \\
98.9 \\
99.0\end{array}$ & $\begin{array}{l}0.01 \\
0.009 \\
0.008 \\
0.007\end{array}$ \\
\hline ヨウ化カリウム & $\begin{array}{c}\text { 水 } \\
50 \% \mathrm{G}\end{array}$ & $\begin{array}{l}0.0552 \\
0.0550\end{array}$ & $\begin{array}{l}99.0 \\
99.1\end{array}$ & $\begin{array}{l}0.003 \\
0.003\end{array}$ \\
\hline
\end{tabular}

測定值は 3 回の平均値

$\mathrm{G}$ ：エチレングリコール, P : イソプロパノール

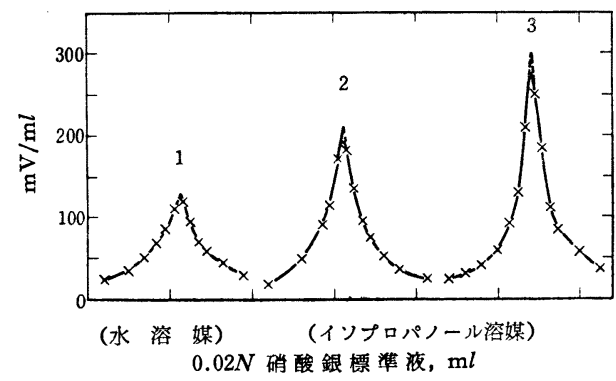

Fig. 2 溶媒による塩化ナトリウム滴定曲線の変化 試料液の溶媒 $1,2:$ 水 $3: 50 \%$ エチングリコール 


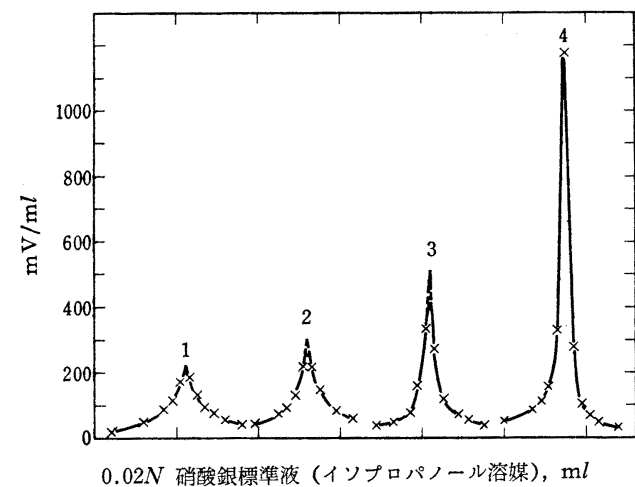

Fig. 3 溶媒の含水量による滴定曲線の変化

$$
\begin{aligned}
& \text { 試料: 塩化カリウム } \\
& \text { 溶媒 } 1: \text { 水 } \\
& 2 \\
& 2: 25 \% \text { イソプロパノール } \\
& 3: 50 \% \text { イソプパノール } \\
& 4: 80 \% \text { イソプロパノール }
\end{aligned}
$$

\section{5 考察}

銀滴定を電位差法で行なうときは, 普通 (1) 式で表わ される電池を使う。

$$
\mathrm{Ag} \mid \mathrm{Ag}^{+} \text {(solv.) } \|_{E_{j}} \mathrm{KNO}_{3} \text { aq. } \| \mathrm{Cl}^{-}\left|\mathrm{Hg}_{2} \mathrm{Cl}_{2}\right| \mathrm{Hg}
$$

試料の溶媒として水を使うときは, 液間電位, $E_{j}$ 厳 密な理論的扱いをするとき以外はほとえど無視できる。 しかし, 溶媒として水以外のものも使うときは $E_{j}$ の值 は大きく，また変動もしやすいという問題が起ってく る. 試料液の溶媒組成が変化しない場合には, 同じ組成 の溶媒を用いた補助電極（基準電極）を使うことによっ て安定な測定ができるが9101，標準液の溶媒と試料液の 溶媒とが違つているときは，その方法も不適当になる。 また，白金，アンチモンなどの金属電極を使うと，液間 電位法存在しないが，その代わりその電極電位が一定で あることも, 再現性を得ることもあまり期待できない. つまり, 有機溶媒を使う滴定, 特に滴定中に試料液の溶 媒組成が変化する場合には, その液間電位をきわめて小 さくし, 安定化できる直接微分滴定法が最もすぐれた方 法であること注，著者が先に報告》したところからも明 らかである. その測定に使う電池は（2）式で表わされ る.

$$
\begin{gathered}
\mathrm{Ag} \mid \mathrm{Ag}^{+}\left(C_{1}\right) \| \mathrm{Ag}^{+}\left(C_{1}-\Delta C\right)[\text { 小量 }] \\
E_{j} \quad[\mathrm{Ag} \text { 遅延 電 極 }]
\end{gathered}
$$

この直接微分滴定法は種々の形式1112)で行なわれてい るが，遅延電極の形が複雑だとその折れ曲った部分やす き間に液がたまり，標準液を加えるたびごとに液の濃度
が均一になりにくいから，遅延電極本体の形はできるだ け単純な方がよい，それが「スポイト電極」8使った 理由であるが，ゴム製の乳首を使って試料液を遅延電極 に出入させる在来の方法では, 電極内の液量を一定にし にくいこと，スポイトが液を吸入するとき乳首が元の形 にもどるのに案外時間がかかることが前の実験りで確か められたので，新しい方法を考案したことによりよい結 果が得られた。

直接微分滴定法で直接求められる一次微分曲線（Fig. 2 打よび 3$)$ はその頂点がやや丸くなるため, 滴定曲線 の両側を外そうして交わった点定終点とした。そそれ法， 測定值から計算と作四とによって求めた二次微分曲線を グラフに描いたときの曲線と横軸との交点を終点とした 場合と測定誤差の範囲内で一致した結果が得られた。

八ロゲンイオンの種類あるいは溶媒による測定感度の 変化を比較するために, Table I の下の式で示したよ うな式で感度を表わしたのは，終点に達するまでに要す る標準液の量が違うことによる起電力の変化を補正する ためである. その值は微分するために一度に加える標準 液の体積 $(0.1 \mathrm{~m} l)$ が小さいために生ずる誤差と, その ときの起電力の変化 $(40 \mathrm{mV}$ 以上) の測定誤差から, そ の測定精度は $\pm 2 \%$ の誤差を含むことになる。

沈殿滴定で法共沈および吸着をいかにして防ぐかが重 要な問題であるが，水のみを溶媒として滴定するときは Tween 20 を0.1〜0.5\% 加えることによってよい成 績をあげることができたが，有機溶媒の含量が多いとき はその効果よりか总って弊害が多くなった．その弊害の 少ない溶媒であるエチレングリコールでは測定感度の向 上は多くなかった。

Fig. 2 および 3 と Table I, II および III から， 溶媒の含水量および溶媒の親水性が減るほど測定感度が 増大することが秝かった、エチレングリコールを用いた ときには，その含量が $80 \%$ になってもあまり感度は向 上しなかったが，イソプロパノールを使ったときには測 定感度の上昇が大きく，特にその含量が $80 \%$ にもなっ てくると急に感度が上って行った．その感度を重量で表 現してみると, 塩化カリウムの場合, 水溶液のみを使っ たとき $3 \mu \mathrm{g}$ であったものが $0.3 \mu \mathrm{g}$ まで向上したこと になる. 溶媒中の含水量を $20 \%$ 以下にすると, 試料液 の電気伝導度が低下し, 反応速度も遅くなり, 測定が急 に困難, 不安定に傾いて行った. そこで実用上イソプロ パノールの含量が $80 \%$ のときが，最も感度のよい測定 条件と考え，その条件で水溶液のみを使ったときとを比 較してみたわけである.

本研究觉行なうにあたり, 御指導, 御援助导いただい 
た京都大学宇野豊三教授, 国立衛生試験所刚米達夫所長 ならびに長沢佳熊部長に感謝の意さ表します。

(昭和 35 年 4 月 5 日, 第 13 回日本薬学大会で発表)

$$
\text { 文献 }
$$

1）鹿島 哲ほか：薬誌， 76, 50, 931 (1956); 衛生 試報，74，9，15 (1956)，78，15（1960）。

2) N. A. Izmailov, E. I. Vail : Ukrain. Khim., 23, 662 (1957) ; Chem. Abstr., 52, 7006 (1958).

3) I. Streipa : Latv. Iauksaimniecibas Akad. Raksti, 1958, 25 ; Chem. Abstr., 53, 21390 (1959).

4) G. R. Waterbury, E. H. Van Kooten, B. Morison : Anal. Chem., 30, 1627 (1958).

5) R. W. Freeman : ibid., 31, 214 (1959).

6) J. G. Hanna, J. Jura : ibid., 31, 1820 (1959).

7) T. Kashima : Chem. Pharm. Bull., 6, 229 (1958).

8) N. F. Hall, M. A. Jensen, S. E. Bachstrom: J. Am. Chem. Soc., 50, 2217 (1928).

9) R. A. Glenn : Anal. Chem., 25, 1916 (1953).

10) N. Al-Qaragnuli, K. G. Stone : ibid., 31, 1448 (1959).

11) D. A. MacInnes et al. : J. Am. Chem. Soc., 48, 2831 (1926) ; 53, 555 (1931) ; Z. physik. Chem., 130A, 217 (1927).

12) A. Kirrmann, N. Daune-Dubois : Compt. rend., 236, 1361 (1953).
Argentimetric titration of halogen ions in mixtures of an organic solvent and water by direct differential potentiometric titration. Tetsu Kashima (National Institute of Hygienic Sciences)

Halogen ions are titrated in mixtures of an organic solvent and water in order to increase the sensitivity of the measurement. The effect of the organic solvent in the mixture has been examined by a direct differential potentiometric titration.

The conventional potentiometric titration in aqueous solution using a cell with a salt bridge would not be applied in the presence of any organic solvent, since the liquid junction potential between an aqueous solution of the salt bridge and an organic solution of the sample is very large and unstable, especially in the course of the titration.

In this paper the author has introduced a direct differential titration method using silversilver retarded electrodes in order to avoid the fluctuation of the liquid junction potentials. Using a "squirt electrode" with a syringe and a three-way glass tube, or a nitrogen gas bomb and a three-way glass cock, the titration is carried out more conveniently and more accurately than the older method using a rubber squirt. The results of the experiments showed that the sensitivity and stability of the measurement were much increased.

(Received Mar. 17, 1962)

\title{
含水溶媒を使った銀-ガラス電極を用いるハロゲンイオンの銀滴定
}

\section{一 滴定中に試料液の溶媒組成を急に大きく変化させる分別滴定一}

\author{
鹿島哲*
}

含水溶媒を使い，無関係電解質としてフタル酸水素カリウムを加えて，ハロゲンイオンを硝酸銀標準 液で滴定するときの，使用する溶媒の種類（イソプロパノール，エチレングリコール，アセトンおよび ジオキサン）とその含水量などの滴定に及ぼす影響总，銀一ガラス電極を用いる電位差滴定で検討した。

標準液の溶媒としてィソプロパノールを使い, 試料液の溶媒として含水アセトンあるいはイソプロパ ノールを使うことにより，溶媒として水のみを使ったときと比較して，塩素イオンの測定精度を 4〜10 倍，臭素イオンのそれ苍 2 〜倍に向上させることができたが，ヨウ素イオンのそれはあまり向上しな かった。

2 種のハロゲンイオンを含む試料觉滴定するとき，まず水のみを溶媒として一方の八ロゲンイオンを 滴定してから，多量のアセトンを加えて滴定学続けるととにより残りのハロゲンイオンを滴定する方法 苨考案した。これにより，2種のハロゲンイオン学一組成の溶媒を使う場合より正確にして精度のよ い分別滴定をすることができた。

\section{1 緒訇}

無関係電解質として弱酸または弱塩基の塩を使う沈殿

* 国立衛生試験所 : 東京都世田谷区玉川用賀町 2 丁目
または酸化還元滴定では，ガラス電極が他の電極より安 定で再現性のよい基準電極（補助電極）の役目をするこ とはよく知られている。しかし，含水溶媒を使うときに は緩衝作用をする塭を含んでいても，滴定中一定の電位 